\title{
Care revolutions in the making? A comparison of cash-for-care programmes in four European countries
}

\author{
VIRPI TIMONEN*, JANET CONVERY† and SUZANNE CAHILL**
}

\begin{abstract}
This article describes and evaluates cash-for-care programmes for older people in four European countries, namely Home-Care Grants in Ireland, Direct Payments in the United Kingdom (England), Service Vouchers in Finland and Personal Budgets in The Netherlands. The purpose is to raise understanding of the background and reasons for the introduction of cash-for-care programmes and their impact on the countries' care regimes. It is argued that while the motives for introducing cashfor-care programmes in the four countries are similar, namely to promote choice and autonomy, to plug gaps in existing provision, to create jobs, and to promote efficiency, cost savings and domiciliary care, the relative importance of these goals varies. Current cash-for-care programmes have comparatively modest coverage as compared with direct service provision and provide no more than an optional, supplementary source of care in three of the studied countries. Cash-for-care schemes have not radically transformed the care regimes in Finland, The Netherlands or the United Kingdom. In Ireland, however, the restricted availability of alternative forms of formal service provision means that the expansion of cash-for-care might shift care provision significantly towards private provision and financing.
\end{abstract}

KEY WORDS - cash-for-care, homecare, older people, social care policy, care regimes.

\section{Introduction}

State cash-for-care programmes offer cash payments or vouchers instead of services-in-kind to (older) people who need care, and they allow a varying level of freedom in their allocation. Several countries have introduced cash-for-care programmes, but there have been few evaluations, although their labour market impacts and whether they promote the

* School of Social Work and Social Policy, Trinity College, University of Dublin.

$\dagger$ Health Service Executive, Bray, Wicklow, Ireland.

** Dementia Services and Information Development Centre, St James's Hospital, Dublin. 
independence of service users have been analysed (Ungerson 2003, 2004). This article focuses on the reasons for the introduction and the key features of four cash-for-care programmes, Home-Care Grants (HCG) in Ireland, Direct Payments (DP) in the United Kingdom (UK), Service Vouchers (SV) in Finland, and Personal Budgets (PB) in The Netherlands. These programmes have been instituted in four countries that represent the contrasting care regimes defined by Anttonen and Sipilä (I996). ${ }^{1}$

The cash-for-care schemes are relatively recent additions to the homecare service options available to older people. Why are countries with different care systems turning to these innovative arrangements, and how are the characteristics of the care regime and other national factors reflected in the design and implementation of the programmes? While it is clear that the social, economic and political reasons for introducing cashfor-care programmes differ greatly, some common themes and aspirations can be identified. It has been remarked that, '[social care services] are a barometer of the balance of the public and private worlds within a society' (Anttonen, Baldock and Sipilä 2003: 2). While it is too early to judge the impact that cash-for-care schemes are having on the care regimes in question, this article provides a first analysis of their impact on the balance between the public and private worlds in social care.

\section{Aims and methodology}

Our study of the four cash-for-care programmes sought understanding of their rationale, of the impact that the programmes are having on the broader care regime, and of the benefits and problems of the new arrangements. Both documentary and primary research have been undertaken. In each country, we contacted four groups of key informants: senior civil servants in the relevant government department who had extensive knowledge of the background and policy processes associated with the introduction and operation of the cash-for-care programmes; senior health services and social services administrators involved in overseeing or monitoring the implementation of cash-for-care programmes 'on the ground'; one or more representatives of national organisations with a special interest in domiciliary care services for older persons; and one or more academics and policy analysts who had worked in the area. In-depth, semi-structured interviews with informants in these four categories were conducted in each case-study country between March and October 2004.

The interview questions and analysis of documentary evidence centred on three broad topics, namely the background and rationale for the 
introduction of the schemes, the service structures and standards, and the perceived problems and challenges of the cash-for-care arrangements. The key themes that emerged from analysing the content of the interviews and documentary materials were: choice and autonomy, regulation, cost, commodification and quality control. These dimensions are explored in detail in the following four case studies and then comparatively in the last two sections of the paper. The principal characteristics of the four cashfor-care programmes are summarised in Table I.

\section{Home-care grants in Ireland}

\section{Background and rationale}

Ireland has comparatively under-developed and poorly co-ordinated community-care services. The Irish welfare state has neo-liberal features in its low level of expenditure, the heavy reliance on the family as 'free' care-givers, and the reluctance of the state to adopt a substantial role in the direct provision of care services to older people (Gonvery 200I; Timonen 2005; Timonen and McMenamin 2002). The subsidisation of private nursing-home care has been a policy priority for Io years, and has been implemented by tax incentives to nursing-home providers, the contract funding of places in private nursing-homes (termed 'contract beds'), and a subvention scheme that covers part of the costs of institutional (nursinghome) care to individuals. Before the introduction of the Home-Care Grants (HCG) in 200I, older people had a statutory entitlement to apply for a public subvention that offset nursing-home fees, but no equivalent right for community-care charges. As a result of the funding bias, many older people with low and medium levels of dependency are in institutional care (O'Shea 2002: 65, 8I).

HCGs can therefore be seen first and foremost as an attempt to counter the institutional bias built into the Irish care system for older people, and as a measure to stem the spiralling public expenditure on nursing-home care. The perception that it would be cheaper than institutional care was a critical factor in gaining the support of the government (Department of Social and Family Affairs 2002). Economic considerations were therefore the main factor driving the new initiative. HCGs also give greater choice in long-term care to older people and their carers, but while arguably they enable older people to live at home, the grants do not mean a complete break with the traditional care model because their success depends on significant inputs from informal carers (who at present cannot be paid with the help of the grants). A review of current grants established that most covered only a small part of (the costs of) the needed care, and that 


\begin{tabular}{lcc}
\hline Financing & $\begin{array}{c}\text { Regulation and } \\
\text { legislation }\end{array}$ & Reach \\
\hline
\end{tabular}

\section{Ireland: Home-Care Grants}

Tax-financed. Until recently discretionary sums have been dedicated by individual health boards, but earmarked budgets now

becoming available.

\section{United Kingdom (England): Direct Payments}

Funded from tax revenue by central government; funds

channelled from existing

local authority budgets.

\section{Finland: Palvelu-Seteli (Service Vouchers)}

Tax-financed.

\section{The Netherlands: Personal Budgets}

Long-term care insurance (AWBZ) financed through payroll contributions - I3\% of income up to a ceiling of $€_{30 k}$. No upper limit.

Income-related co-payments up to a maximum
Began 200r. Currently at the discretion of individual health

boards; more definite national guidelines emerging.

As yet no firm legislative footing.

\section{Available to older people} since 2000. Local authorities obliged to offer DP to all those eligible since 2003 but take-up varies greatly by local authority.

Entitlement to vouchers,

but not obligated (generic services can be demanded). Began in 2004 (pilot projects in the I990s).

Some $55^{\circ}$ recipients in 2004 , but likely to increase to around 5,000 in 2006/o7.

6,ooo recipients in England in $2003 / 04(0.04 \%$ of $65+$ years and $0.6 \%$ of community-care recipients). Substantial growth likely after recent commitment to raise funding.

Numbers growing, but not intended to expand beyond I0 $\%$ of all home-care recipients.

Approx. 30,ooo older people (aged 55 + years) among PB holders $(0.8 \%$ of the regulated. Independent agencies deal with assessment of need, pay and working conditions. Trades union have a role in supporting and training care-assistants.
Contributes to development of community care that to date has relied on informa care (with institutional care as a last resort). Gives older people care choices.

Care management services and direct payment support services in place.
Broadening choice; some evidence of employment-creation.

Some unpaid care has been substituted by paid care.

Gives choice to older people. Acknowledges family contribution to care. Entitlement to

$\mathrm{PB}$ : genuine choice between $\mathrm{PB}$ and direct services.
Insufficient dedicated funding; limited availability and area differences; inadequate controls; unregulated homecare market; cannot be paid to family members.

Funding arrangements precarious; difficult to

engage carers; onerous audit and admin. demands; sparse information; no guidelines and much local variation in funding.

Limited in scope; low uptake. Older persons do not have a right to vouchers (but do have a right to in-kind services).

Some funding moved out of AWBZ to municipalities; fear that entitlement will be undermined; system holds family carers (living with the older person) responsible for many household and caring tasks. 
three-quarters of $\mathrm{HCG}$ recipients had to draw on private funds or informal care (or both): without informal carers and private expenditure, in the majority of cases the grant would be unworkable (Timonen 2004).

\section{Service structures and standards}

The care needs of applicants are assessed by public-health nurses or medical social workers, who act as gatekeepers to the system in that they identify the older people most in need of the grants. The availability of appropriate community services, such as home-help, care assistants and day care, must be established before the grant is made. In other words, the grant is designed to supplement, rather than replace, formal and informal services that are in place, but in many cases the formal provision is patchy and inadequate and the grant becomes the only route to significant provision of in-home care.

The degree of choice and autonomy enjoyed by HCG recipients varies by health authority. In some areas, prospective ('up-front') payments are made to individual recipients who are free to allocate the money as they wish: the older person or a family member assumes the role and responsibility of employer and indeed all responsibility for the use of the grant (East Coast Area Health Board 2003). In other areas, payments are retrospective and made directly to the for-profit care agencies that deliver the services (Northern Area Health Board 2003). While non-profit agencies are in some areas involved in delivering the services purchased through HCGs, approximately go per cent of grant recipients hire a private-sector agency or an individual care worker (Timonen 2004). There are currently no independent attempts to measure the standards of service or the level of supervision or training provided to their staff by private-care agencies.

\section{Problems and challenges}

The lack of regulation of the HCG schemes leads to the suspicion that some care workers are outside the tax system, thus depriving the state of revenue and the workers of social benefits and protection against exploitation. The grant seems to work best for older people who have a family member who can take responsibility for recruiting, employing and paying carers, and who can also meet the care needs (and costs) that the grant does not cover. While the HCGs are in principle optional additions to community-care services, these are so scarce that the HCGs are becoming 'the only game in town'. The government will expand the number of HCGs by several thousand packages in 2006/o7 (Anon 2005 $a, 2005 b$; Department of Finance 2005). In the absence of any other investment in 
public home-care services, the expansion is a shift towards private-sector provision.

\section{Direct payments in the United Kingdom}

\section{Background and rationale}

The Direct Payments (DP) system in the United Kingdom (more precisely, in England) has its origins in the demands voiced by the disability rights movement for greater autonomy and choice. The community-care provisions of the National Health Service and Community Care Act I9go removed eligibility to DP for people aged 65 or more years (because of a concern about escalating costs), but since February 2000 the entitlement has been restored, and since April 2003 under the Health and Social Care Act 200I, local authorities have been obliged to offer DPs for all with care needs. In 2002, the UK Department of Health called for an expansion in the number of DP recipients, especially among older people. ${ }^{2}$ The Department is currently making substantial investments in this programme through the Direct Payments Development Fund, and between 2003 and 2006 it hopes to expand the number of recipients to several tens of thousands (Department of Health (England) 2002). The number of DP recipients has already increased rapidly: in 200I-02 only goo people aged 65 or more years received DP, but by 2003-04 there were 6,000 recipients. Despite this strong growth, DPs were received by only 0.04 per cent of the population aged 65 or more years in England, and by only o.6 per cent of older people who received community-care services (Department of Health 2004; Organisation for Economic Cooperation and Development (OECD) 2005).

According to Clark, Gough and Macfarlane (2004: 3), 'extending direct payments is part of the modernising agenda for social care' (our emphasis). A central part of this modernising agenda is that, '[p] eople ... have the opportunity to choose what services and support they think would best meet their needs ... [these] might be different from the services that the formal care system has on offer' (our emphasis) (Department of Health 2005: 33). In other words, as this article argues, the DPs are a tool for reducing the role of direct service provision (that is portrayed as out-of-date and unresponsive), and for increasing the role of other service providers (that are seen to be more flexible and user-friendly, and possibly also cheaper). ${ }^{3}$

\section{Service structures and standards}

Case managers and social workers in local authority social services departments carry out the needs assessments, and design the care plans. 
The hours of care needed are identified and determine the budget allocation. Care managers play an important role in distributing information about DP and in helping recipients to organise their services. While there is evidence that care managers in some cases exercise excessive gatekeeping and paternalism, the fact that care managers have a role in the DP system is probably one of the main strengths of the English scheme. The care plans are reviewed every six months and, where necessary, changes are made to the DP arrangement.

Under the Fair Access to Care Assessment Act 2003, in principle DP can be used to purchase any type of service required by the care plan, including social and leisure activities, but in practice most payments for older people are used to purchase personal care and domestic services. Older people with DP may receive other health and social services. DP recipients can engage an individual worker or employ someone through an agency and, in either case, are required to draw up a contract with the worker. In general, older people prefer to hire agency staff or people known to them, and are allowed to use the DP to pay a non-resident relative (or 'informal carer'). A means-tested co-payment is payable by the DP recipient. Home-care agencies are registered in the UK and there is some effort to ensure minimum standards of service by requiring the agencies to demonstrate that they have vetted their staff and provided staff training. Quality assurance is inevitably more difficult if independent workers are used, although many recipients choose individuals known to them; while this may provide protection for some, others are likely to be vulnerable.

\section{Problems and challenges}

There is, in theory, no upper limit to the amount of funding available to individuals under the DP scheme, although budget limitations mean that most local authorities are under pressure to keep DP costs down. As in Ireland, the level of funding in many cases falls significantly below the cost of the required services. The interviews conducted for this research suggested that some local authorities limited eligibility to applicants with a high level of functional ability, and that those with communication or mental health problems were often deemed ineligible (see also Rankin and Regan 2004). There is much variation among local authorities: the schemes are miniscule in some authorities, but others have implemented the scheme enthusiastically (Audit Commission 2004). The take-up of DPs has been low, but the number of recipients is expected to grow significantly (Clark, Gough and Macfarlane 2004). Barriers to take-up include a lack of information, low staff awareness of the DP option, the 
reluctance of some professionals to hand over control of funding to service users, and opposition to the scheme from some Labour-controlled local authorities and public-sector trades unions. The current regulations stipulate that both DP recipients and the care workers paid through the scheme must set up a personal bank account for that purpose, which creates a bureaucratic barrier for many applicants (Audit Commission 2004).

\section{Service vouchers in Finland}

\section{Background and rationale}

The 'rainbow' coalition government that introduced the Home-Care Service Vouchers (SV) in Finland during the late iggos saw them as a vehicle for increasing service users' freedom of choice and for stimulating private sector provision. ${ }^{4}$ The development of the voucher scheme should be seen against the backdrop of the I99os recession and the ensuing cutbacks of the (public) home-help services. Whereas in ig88 nearly one-half $(46.2 \%)$ of those aged 75 or more years received home-help (predominantly household or domestic services), by 2000 the percentage had fallen to just under 25 (Vaarama and Voutilainen 2002; National Research and Development Centre for Welfare and Health, Finland 2003). Home-help services are now targeted towards older people with the greatest care needs, and in many areas domestic-care services (cleaning etc.) are increasingly delivered by private and voluntary sector organisations. The SV system is first and foremost an attempt to compensate for the reduction in municipal home-help services, and its secondary aims are to foster job creation in the private and not-for-profit sectors and to reduce the costs of service provision, as explicitly stated in some policy documents (Sosiaali- ja terveysalan Tutkimus- ja Kehittämiskeskus 2003).

The first expert report on the SV system suggested that the scheme should stimulate competition between the public and the private sectors by allowing voucher recipients to choose any public or private sector provider in their area (Suominen and Valpola 2002). It is of interest, however, that this suggestion was deemed too radical by many of the actors in the process, and public providers are now outside the voucher system. The limitations and safeguards that are built into the current system were sufficient to placate most critics of the voucher system so that, for instance, the municipal workers' union is now, broadly speaking, content with the scheme. The SV system will be evaluated in 2006, with a view to its wider adoption, as for residential care and health care. 


\section{Service structures and standards}

The service vouchers are financed through general tax revenue and can be used to pay for (part of) the costs of home help, but not for home nursing (Räty 2004). The service voucher is not a right, nor does it have to be taken up by individuals in need. Municipalities must also offer their 'own' services, i.e. public services that are not tied to the voucher system continue to be provided. The intention is that in the medium term 'voucher services' will amount to approximately one-tenth of home-help provision in the country (Government Proposal (Finland) 74/2003). The value of the $\mathrm{SV}$ varies depending on the client's income, level of need and the number of people living in his or her household. The cost of the service over and above the value of the service voucher has to be met by the service user. The user fees (i.e. the cost share paid by the service user) for clients who need regular services are tightly regulated to ensure that they are modest in relation to the client's income (Ministry of Social Affairs and Health I999b). The cost of services to an individual using the vouchers is not higher (and can in some cases be marginally lower) than the cost of using municipal services.

An applicant's needs are assessed by a municipal-care team, and this assessment is reviewed every six months. A care plan is drawn up together with the client, who is then informed of the alternatives (direct service provision or using the SV to contract with approved providers). A contract provider charges the amount detailed on the voucher from the municipality and additional costs to the client. It is expected that the high quality services or the price-quality ratio (i.e. value for money) offered by some providers will make them more attractive than others, thus both rewarding 'good' providers and delivering benefits to service users. While the quality of services delivered under the voucher schemes may yet become an issue, there are several safeguards to ensure minimum standards and accessible complaints procedures. The municipalities are responsible for ensuring that services are delivered by reputable companies and organisations that are registered with the tax authorities and meet minimum staff-training and equipment standards. The clients who receive services under the voucher scheme can lodge complaints with the municipality, and district governments are authorised to investigate complaints and substandard services.

\section{Problems and challenges}

The suitability of the voucher system for some client groups, such as people with dementia, has been called into question. The task of choosing from and co-ordinating myriad service providers is beyond the capability of 
people with cognitive impairments. The Alzheimer Society of Finland believes that funding should be prioritised for public services because they are userfriendlier for people with dementia (Tervonen 2004). All levels of the policy-making system acknowledge that the vouchers are not suitable for all groups of older people (Minister for Social Affairs and Health, Finland 2003).

While some cities and municipalities in Finland have many competing enterprises that offer home-help services, others have no private providers at all. It is intended that municipalities foster competition and lower prices through open tenders for the service contracts. While the municipalities are permitted not to accept tenders from service providers deemed unsatisfactory, in some areas there will be few or no competitors (Koskiharju and Seppänen 2004). As the municipalities have limited resources and their direct service provision is unlikely to be able to meet the demand, in the medium and long term the most likely source of funding for extra or better services will be private payments. The universal and egalitarian principles underlying the Finnish welfare state may be gradually undermined if better-off individuals choose to pay higher service charges, for this will progressively differentiate high-quality, improving and expensive private-sector services from the lower quality (and possibly declining) public services for less well-off clients (Heikkilä, Kaakinen and Korpelainen 2003). Some observers believe that the voucher system will lead to a gradual shift in the responsibility for care costs from the state to individuals (Suominen and Valpola 2002).

\section{Personal budgets in The Netherlands}

\section{Background and rationale}

Long-term care in The Netherlands is a right: once the need for services is established, the state has a responsibility to ensure that these are delivered (Pijl I993). The fundamental motive for the introduction in I995 of Personal Budgets (PB) appears to have been the desire to offer genuine choice and more flexibility to people in need of care (originally people with disabilities, subsequently other groups including older people), although another factor was the need to reduce waiting lists for direct service provision (Wiener 2003). The introduction of $\mathrm{PB}$ was in fact expected to increase care costs, i.e. their introduction was not motivated by cost containment. By 2003 the largest and most important group of budget holders was older people, for of the approximately 63,00o recipients, $5^{\circ}$ per cent were aged 55 or more years. 
Personal budgets and public long-term care supports in The Netherlands are financed through social-insurance contributions. Total expenditure on the PB amounted to approximately one-quarter of total expenditure on home care in 2003, a much higher share than in the other three featured countries. Nonetheless, many fewer older people benefited from $\mathrm{PB}$ than received home-care: while some i2 per cent of those aged 65 or more years received some form of public home-care, only o.8 per cent received PB-funded services (Lundsgaard 2005). The proportion of older people in residential care in The Netherlands has declined sharply, from approximately nine per cent in the I980s to less than five per cent in 2005, which has been attributed to changed preferences, better home-care services and the availability of PB (de Klerk 200 ; OECD 2005).

Several fundamental changes were introduced to the PB system in April 2003. Most importantly, people in need of care became entitled to help with specific functions rather than the help of specified agencies or organisations. This change was intended to break the virtual monopoly held by established providers and to stimulate competition, by switching from a supply-oriented to a demand-oriented system, and it has contributed to an increase in the number of private-sector providers and of providers that specialise in one or two functions (Huijbers 2004).

\section{Service structures and standards}

The assessment of care needs is carried out by the Centrum Indicatiestelling Zorg (CIZ) [Care Indication Determination Office]. The assessment is undertaken by a multi-disciplinary team of social workers, doctors and nurses, and includes a visit to the client's home. CIZs are independent careassessment agencies that are not beholden to the insurance institution. It appears, however, that cost considerations influence both the criteria used in the assessment of care needs and the recommended forms and packages of care. For instance, a person with very extensive care needs is usually referred to institutional care because home-care would be much more expensive. Interest groups such as the Vereniging van Mantelzorgers [Dutch Carers' Association] believe that the assessment process is too concerned with the availability of an informal carer in the household: there is a list of duties that family members are supposed to carry out without payment, which many carers believe excessive. Following the assessment and determination of the level of payments and co-payments, the person in need of care chooses either direct services or cash-for-care. Most of the former are provided by established home-care organisations and notfor-profit agencies (College voor Zorgverzekering 2005).

In principle, there is to upper limit to an individual's $\mathrm{PB}$, but in practice the maximum daily allowance set by the CIZs in 2004 varied between 
$€_{200}$ and $€_{300}$. Co-payments vary by income and function and are identical in the direct provision and $\mathrm{PB}$ systems. $\mathrm{A} \mathrm{PB}$, however, is 75 per cent of the cost of the equivalent direct services because the overhead costs of PB providers are lower: increased cost-effectiveness and 'value for money' are claimed merits of the scheme. People on low incomes pay very little in co-payments, regardless of their care needs. In 2005, the minimum was $€_{210.60}$ for the year, and the maximum co-payment was $€ 6,978.40$ (College voor Zorgverzekering 2005). The co-payments were increased sharply in 2003, which has suppressed demand from those with aboveaverage incomes because their co-payments are high, especially in comparison with independent purchases of care on the grey market. The amount paid under the $\mathrm{PB}$ system does not vary by whether the provider is informal or formal. Approximately one-fifth of PB holders opt for an informal carer (typically a family member) (Van den Berg et al. 2002). Regardless of whether the care recipient wishes to engage an informal or a formal carer, they are required to make a contract.

The payments to informal carers through PB are the only form of state remuneration to carers in The Netherlands. Although the PB have transformed the situation of many informal carers, the vast majority still do not receive any financial reward. Those employed by their own family members are not registered with the social insurance system and therefore do not acquire rights to pensions (although they are entitled to holidays). The quality of care is currently not perceived to be a major problem in The Netherlands, and at the time of the interviews (Summer 2004) there were no waiting lists for home-help services. The poor co-ordination of services is, however, an issue. Many PB holders employ several care providers, partly because the responsibilities of an employer (e.g. paying social insurance contributions) are avoided if a person is employed for no more than two days per week. In other words, a person that needs care six days a week avoids many administrative duties if they engage three different carers. As a result, only around five per cent of PB holders are full-time employers.

\section{Problems and challenges}

The Netherlands government perceives the financial sustainability of the long-term care system to be a problem. ${ }^{5}$ The desire to cap spending appears to be the main motivation behind the planned transfer of 'social supports' (housekeeping, supportive attendance and activating attendance) out of the social insurance system and to a municipal responsibility. Under the proposed legislation, municipalities will not receive earmarked funds for providing these social supports, but there will be an adjustment 
to their block grant. In practice this will mean that the availability of the 'social aspects' of long-term care will depend on the competing demands upon municipal funds.

Another significant recent change has been that the CIZ assessment boards are taking 'available family support' more carefully into account when determining care needs. Protocols have been established about the parameters of family responsibility, to which carers are expected to adhere. Varying levels of informal care and self-care are expected from co-resident family members, even from the age of $\mathrm{I} 2$ years - a child of this age is expected to make their own bed, while a spouse is expected to bathe their dependent spouse, and so on. There are, however, no expectations of non-co-resident family members, e.g. a son or daughter living nearby is not expected to provide care. The rules governing reasonable input from family members are guidelines rather than binding regulations, and their application varies across the assessment boards.

\section{Comparative analysis}

In terms of their design and implementation, the four programmes have much in common: all have been introduced recently and are, with the possible exception of the Dutch scheme, being expanded. All four schemes are also in principle optional for older people in need of services (in that they can opt for direct service provision instead). In each country, the predominant service providers are private-sector agencies and selfemployed individuals (although two of the schemes also allow relatives and other 'informal' carers to be hired). But the schemes also differ in many crucial respects, most importantly in the levels of commodification, employment regulation, cost coverage and quality controls. The cash entitlement can be used to 'commodify' informal care work, i.e. to employ relatives as care workers in The Netherlands and in England, but not in Finland and Ireland. The employment created and the care purchased through the scheme is part of the mainstream, taxed and regulated economy in England, The Netherlands and Finland, but less so in Ireland. ${ }^{6}$ The proportion of the costs of care covered by the cash-for-care payment or voucher is high in Finland and The Netherlands, moderate in England, and in most cases low in Ireland: in other words, the Irish and the English schemes place more responsibility for costs on individuals (and families). The quality of services purchased with the cash entitlement is only haphazardly monitored in Ireland, while there are some quality controls in England, and comprehensive monitoring takes place in Finland and The Netherlands. 
T A B L E 2. Key factors influencing the creation and design of cash-for-care programmes in Ireland, England, Finland and The Netherlands

\begin{tabular}{lcccc}
\hline Rationale for introduction & Ireland & England & Finland & Netherlands \\
\hline $\begin{array}{l}\text { Promote clients' choice } \\
\text { Promote clients' autonomy }\end{array}$ & & $\sqrt{ }$ & & $\sqrt{ }$ \\
$\begin{array}{l}\text { Compensate for gaps in } \\
\text { service provision }\end{array}$ & $\sqrt[V]{ }$ & $\checkmark$ & \\
$\begin{array}{l}\text { Job creation } \\
\text { Efficiency and cost considerations }\end{array}$ & $\sqrt{ }$ & & $\sqrt{ }$ \\
$\begin{array}{l}\text { Shift in preference from institutional } \\
\text { to home-care }\end{array}$ & $\sqrt{ }$ & & \\
\hline
\end{tabular}

Why were cash-for-care programmes introduced in the four countries? The 'noble' aim of giving older people greater choice and control over their lives was an important factor (Glendinning et al. 2000), but it is clear that merely switching from direct service provision (or its unavailability) to cash payments does not in itself enhance choice and control. Indeed, it is arguable that complicated cash-for-care arrangements reduce control and oversight for some user groups (Ungerson 2004). It is also doubtful whether the desire to extend choice and control is the main motive behind the introduction of cash-for-care programmes. We argue that the cash-forcare schemes in all four countries have similar goals: increased freedom of choice, independence and autonomy for care recipients; to compensate for gaps in existing services; to create jobs in personal-care services; to make efficiency gains or cost savings through reduced overheads and increased competition among providers; and to shift care preferences and utilisation from institutional to domiciliary care (Table 2).

The relative importance of these goals has varied, however, in each country. Table 2 summarises the rationales for, and influences upon, the four schemes as reported to us by the key informants. It makes clear, for example, that the cash-for-care programmes in England, Finland and Ireland were introduced to compensate for (perceived) deficiencies in, or a lack of, direct service provision. It has been remarked that, '[d]irect payments [in England] may prove one of the ways in which SSDs [local authority social service departments] can meet the shortfall in domiciliary provision in some parts of the country' (Clark, Gough and Macfarlane 2004: 6). Nonetheless, choice and autonomy considerations have been prominent in the UK debate on cash-for-care. In Finland, Service Vouchers are seen as a mechanism for addressing the increasing gap between the growing demand for care services and the retrenchment of municipal home help, and as a vehicle for job creation in the care-services sector. The introduction and expansion of Home-Care Grants in Ireland reflected 
the reluctance to invest more in direct service provision, the ambition to control the growing public expenditure on institutional care, and the view that institutional care is expensive and inappropriate for many older people. Efficiency gains and increased competition in care services provision were also important motives. A central aim of the PB system in The Netherlands was to stimulate competition and to break the near monopoly of the established home-care organisations, although choice and autonomy were also emphasised.

\section{Implications of the cash-for-care schemes for care regimes}

The detailed implementation of a national cash-for-care programme reflects the country's welfare and social care regime, and the consequences for the regime are also country-specific. In The Netherlands, reflecting the corporatist tradition, the long-term care system is insurance-based, so that Personal Budgets and other elements of long-term care insurance are seen as rights: individuals are entitled to a level of payment or services corresponding to their need for care. While payments made through the PB schemes are subject to an income-related co-payment, they are in principle unlimited, reflecting the rights-based approach. The fact that family carers can also receive payments through $\mathrm{PB}$ indicates a degree of 'commodification' of care work, but very few informal carers receive this payment. ${ }^{7}$ Recent plans to shift some housekeeping-related elements of the PB to the municipalities indicate a desire on the part of the current Dutch government to limit long-term care expenditure.

In Ireland, social expenditure is a low proportion of the gross domestic product, and the country's welfare regime can be described as neo-liberal and residual; it relies heavily on means-tested payments and private insurance, and there is low direct service provision. The introduction of the Home-Care Grant scheme reflects a wish to continue to restrain the state's direct involvement in care-services provision. HCGs in their current form will stimulate private-sector care and may lead to an unregulated market in home-care services that offers little or no employment protection, social security rights or professional development and training. The experience of countries with similar cash-for-care programmes suggests that, as HCGs proliferate, the role of international migrant workers will increase (Ungerson 2004). In the United Kingdom, the Direct Payments experiment has not (and was not designed to) address the problems associated with the strong division between health and social care services. The shortfall in direct service provision for older people is replicated in the DP system, and the entitlement is usually a small fraction of the required 
hours of care, with the result that private expenditure and informal care continue to make crucial contributions. The role of more 'flexible' (i.e. nonstate) service providers is expected to increase with the expansion of DPs.

In Finland, the introduction of Service Vouchers was a small but significant departure from the traditional Nordic model of direct service provision. The voucher system has explicitly been designed to foster increased competition and efficiency in service provision for older people, but SVs apply only to private-sector services and public-sector providers are shielded from competition. Finnish policy makers envisage that the voucher system will cover, at a maximum, io per cent of all home-care services, but will expand the role of private providers.

\section{Conclusions}

This article has examined the broad similarities and the main differences in cash-for-care programmes in four European countries, and focused on the rationale for their introduction and the impact of the schemes on the care regimes. It has been argued that the introduction of cash-for-care programmes reflected a reluctance to expand direct service provision by the public sector or quasi-public-sector providers, and the wish to increase the role of private providers (whether in the formal, informal or grey markets). As state funds are increasingly used to purchase care in the private market and to facilitate informal care, cash-for-care programmes blur the boundary between public and private responsibility. While the four cashfor-care programmes examined in this study have similar aims, namely (i) to increase autonomy, (ii) to broaden choice, (iii) to compensate for gaps in direct service provision, (iv) to facilitate more home-based care, (v) to create employment, and (vi) to improve efficiency and reduce costs, the relative importance of these aims differ substantially, as do the design and operating principles of the programmes.

Some of the distinctive features of national welfare regimes are reflected in the new schemes, for instance the Dutch and Finnish schemes are considerably more regulated than the Irish, and three of the programmes are tax-financed, whereas the Dutch Personal Budgets are financed through insurance contributions, in line with the country's other social protection programmes. Nonetheless, several interesting departures from established models have been evident: in Ireland, no community-care subvention existed before the introduction of the Home-Care Grants; in Finland, Service Vouchers are encouraging competition, efficiency and private-sector involvement; in England, Direct Payments are an element of the 'modernisation agenda' and designed to expand the range of providers; and in 
The Netherlands, Personal Budgets represent the first step towards the commodification of informal care.

While representing significant new departures in each of the four care regimes, because of the limited scope and 'optional' status of three of the programmes, it is difficult to argue that they constitute a fundamental reform of the welfare system. The Irish scheme is the only one that has significant potential in the short to medium term to shift the balance of the responsibility for care provision towards private-sector providers and individual responsibility. As the Home-Care Grants are to be expanded significantly without any increase in expenditure on direct service provision, many older people in Ireland will have no choice but to take up the grants - a sharp contrast with the other three schemes that offer a genuine choice between cash-for-care programmes and direct services. In Ireland, the strongest lobbying for the cash-for-care scheme is not from the country's older people but rather the policy makers who have a strong preference for 'public-private partnerships' and believe that cash-for-care will help to control public expenditure.

\section{Acknowledgements}

We warmly thank the individuals who were interviewed for this study, and the Irish Research Council for the Humanities and Social Sciences for financing the project.

\section{NOTES}

I Finland represents the universal, Nordic model with extensive and direct public service provision; The Netherlands the subsidiarity model in which social insurance pays for services largely delivered by voluntary organisations; and England the means-tested model in which direct service provision for older people in need of longterm care is restricted and reserved for the worse-off. The family-care model (with elements of the means-tested model) is represented by Ireland, where direct service provision has been even more modest, and informal family-care is relied upon to provide the bulk of care needed by older people.

2 The Department for Health in London has direct responsibility for the management of health and social care services only in England and, until the Northern Ireland Assembly is reconvened, in Northern Ireland. Policies and management of the statutory health and social care services are a devolved responsibility of the Scottish Parliament and the Welsh Assembly.

3 Research by Zarb and Nadash (1994) indicated that support financed through DP was on average $3 \mathrm{O}^{-} 4^{\mathrm{O}}$ per cent cheaper than equivalent direct service provision.

4 Subsequent governments and official reports have also supported the voucher system: see, for instance, the Programme of the Vanhanen Government, and the final report of the expert group of the National Project for the Development of Social Services by Heikkilä, Kaakinen and Korpelainen (2003).

5 It is estimated that the cost of long-term care will rise to $€_{40}$ billion per year by 2020 (the current annual expenditure is approximately $€_{20}$ billion) and that the insurance 
premium would have to rise to 25 per cent by that year (currently I3.25\%). It is also estimated that by 2020 one-in-three school-leavers would have to be employed in the care sector to meet the demand (from a presentation, 'Care for the elderly, with special reference to the personal care budget', Ministry of Health, Welfare and Sport, I8 June 2004).

6 Ungerson (2004) identified these two factors (commodification and employment regulation) as crucial in determining the outcomes of the cash-for-care programmes for care-recipients and care-givers.

7 Ungerson's (2004) analysis of cash-for-care programmes concluded that a commodified form of informal care had emerged in The Netherlands (where relatives are paid for the care). While Ungerson correctly identified the emergence of a commodified form of informal care in The Netherlands, the development should not be exaggerated. 'Personal Budgets' remain the only form of monetary reward or compensation for informal carers and, following a recent reform, the payments are not to the carer but to the care recipient, who is expected to 'route' it to the carer.

\section{References}

Anon $2005 a$. Harney plan for elderly care in their homes. The Irish Times, 29 September, I. Anon $2005 b$. Budget to deliver home help services for elderly. The Irish Times, 6 December, I.

Anttonen, A. and Sipilä, J. I996. European social care services: is it possible to identify models? Fournal of European Social Policy, 6, 2, 87- Ioo.

Anttonen, A., Baldock, J. and Sipilä, J. (eds) 2003. The Young, the Old and the State: Social Care Systems in Five Industrial Nations. Edward Elgar, Cheltenham, Gloucestershire.

Audit Commission (UK) 2002. Integrated Services for Older People: Building a Whole System Approach in England. Audit Commission, Londona.

Audit Commission (UK) 2004. Supporting Frail Older People. Audit Commission, London.

Clark, H., Gough, H. and Macfarlane, A. 2004. 'It Pays Dividends' : Direct Payments and Older People. Policy Press, Bristol.

College voor Zorgverzekering (GVZ) [Health Care Insurance Board] 2005. Personal Budgets. GVZ, Diemen, The Netherlands.

Convery, J. 200I. 'Ireland'. In Blackman, T., Brodhurst, S. and Convery, J. (eds), Social Care and Social Exclusion: a Comparative Study of Older People's Care in Europe. Palgrave, Basingstoke, Hampshire.

De Klerk, M. (ed.) 200I. Report on the Elderly in The Netherlands. Social and Cultural Planning Office of The Netherlands, The Hague.

Department of Finance (Ireland) 2005. Summary of 2006 Budget Measures: Policy Changes. Stationery Office, Dublin.

Department of Health (England) 2002. Community Care (Direct Payments) Act 1996: Draft Consultation Policy and Practice Guidance to Direct Payments. Department of Health, London.

Department of Health (England) 2004. Community Care Statistics 2003-04: Referrals, Assessments and Packages of Care, England. Department of Health, London.

Department of Health (England) 2005. Independence, Well-Being and Choice: Our Vision for the Future of Social Care of Adults in England. Green Paper, Department of Health, London.

Department of Social and Family Affairs (Ireland) 2002. Study to Examine the Future Financing of Long-Term Care in Ireland. Stationery Office, Dublin.

East Coast Area Health Board (Ireland) 2003. Guidelines for Home-care Grant Applicants. Internal protocol, ECAHB, Dublin.

Glendinning, C., Halliwell, S., Jacobs, S., Rummery, K. and Tyer, J. 200o. Buying Independence. Policy Press, Bristol. 
Government of Finland 2003. Programme of the Vanhanen Government. Government Offices, Helsinki.

Government Proposal (Finland) 2003. Hallituksen esitys Eduskunnalle laeiksi sosiaali- ja terveydenhuollon suunnittelusta ja valtionosuudesta annetunlain $4 \S: n$, sosiaalihuoltolain sekä sosiaali- ja terveydenhuollon asiakasmaksuista annetun lain I2 §:n muuttamisesta [Government Proposal to the Parliament for Laws on the Planning of Social and Health Services]. HE 74-2003 vp, Government of Finland, Helsinki [Available online at http://finlex.fi/linkit/he/20030074].

Heikkilä, M., Kaakinen, J. and Korpelainen, N. 2003. Kansallinen sosiaalinen kehittämisprojekti [National Project for the Development of Social Services]. Final report, Working Paper II, Ministry of Social Affairs and Health, Helsinki.

Huijbers, P. 2004. Older People and Health Care in The Netherlands: Country Report. INTRA conference, The Hague, 2 I-23 June.

Koskiharju, E. and Seppänen, M. (eds) 2004. Vaihtoentona palveluseteli: Lahdenseudun vïden kunnan palvelusetelikokeilu [The Service Voucher as an Alternative: Evaluation of a Pilot in Five Municipalities]. Ministry of Social Affairs and Health, Helsinki, 8.

Lundsgaard, J. 2005. Consumer Direction and Choice in Long-Term Care for Older Persons, Including Payments for Informal Care: How Can It Help Improve Care Outcomes, Employment and Fiscal Sustainability. Health Working Paper 20, Organisation for Economic Cooperation and Development, Paris.

Minister for Social Affairs and Health (Finland) 2003. Vanhustenhuollon tulevaisuus [Future of Older People's Care]. Speech by Sinikka Mönkäre, Minister for Social Affairs and Health, 5oth anniversary celebration of the Association for Old Age and Neighbourhood Service, Ministry of Health and Social Affairs, Helsinki.

Ministry of Social Affairs and Health (Finland) I999 a. Omaishoitajien tuen tarve ja palvelusetelillä järjestetty tilapäishoito [Report on a National Trial of Service Vouchers for Respite Care]. Report Io/ı999, Ministry of Social Affairs and Health, Helsinki.

Ministry of Social Affairs and Health (Finland) I999 b. Vanhuspolitiikka [Policy Towards Older People in Finland]. Sosiaali- ja terveysministeriö, Helsinki.

Northern Area Health Board (Ireland) 2003. Funding of Care at Home. Internal protocol, Northern Area Health Board, Dublin.

Organisation for Economic Cooperation and Development (OECD) 2005. Long-term Care Policies for Older People. OECD, Paris.

O'Shea, E. 2002. Review of the Nursing Home Subvention Scheme. Stationery Office, Dublin.

Pijl, M. A. I993. The Netherlands. In Munday, B. (ed.), European Social Services. European Institute of Social Services, University of Kent, Canterbury, Kent, 273-305.

Rankin, J. and Regan, S. 2004. Meeting Complex Needs: The Future of Social Care. Institute for Public Policy Research, London.

Räty, T. 2004. Palvelusetelit sosiaalipalveluissa [Vouchers in Social Services]. Discussion Paper 340, Government Institute for Economic Research, Helsinki.

Sosiaali- ja terveysalan Tutkimus- ja Kehittamiskeskus (STAKES) [National Research and Development Centre for Welfare and Health] 2003. Ikääntyneiden sosiaali-ja terveyspalvelut 2002 [Care and Services for Older People 2002]. STAKES, Helsinki.

Suominen, R. and Valpola, O. 2002. Palvelut kotiin setelillä? Selvitys palvelusetelin käytön tehostamisesta kunnan kotipalveluissa [Analysis of the Use of Service Vouchers in the Delivery of Home-care Services]. Working Paper 2002: Io, Ministry of Social Affairs and Health, Helsinki.

Tervonen, S. 2004. Tksin asuvien dementoituvien ihmisten selviytymisestä ja tuen tarpeista [Service Needs of People with Dementia]. Alzheimer Society, Helsinki.

Timonen, V. 2004. Evaluation of Homecare Grant Schemes in the NAHB and ECAHB. Eastern Regional Health Authority, Dublin.

Timonen, V. 2005. Irish Social Expenditure in a Comparative International Context: Epilogue. Institute of Public Administration and Combat Poverty Agency, Dublin. 


\section{4}

Virpi Timonen, Janet Convery and Suzanne Cahill

Timonen, V. and McMenamin, I. 2002. Future of care services in Ireland: old answers to new challenges? Social Policy and Administration, 36, I, 20-35.

Ungerson, C. 2003. Commodified care work in European labour markets. European Societies, 5, $4,377-96$.

Ungerson, C. 2004. Whose empowerment and independence? A cross-national perspective on 'cash for care' schemes. Ageing EO Society, 24, I89-212.

Vaarama, M. and Voutilainen, P. 2002. Kaksi skenaariota vanhusten kotipalvelujen kehityksestä ja resurssitarpeesta ajalla 1999-2030 [Two Trajectories for the Development and Resource Implications of Home-Care Services for Older People in 1999-203o]. Thteiskuntapolitiikka [Public Policy], 67, 4, 313-45.

Van den Berg, B., Van Exel, N. J. A., Van den Bos, T., Koopmanschap, M. A. and Brouwer, W. B. F. 2002. Mantelzorg en Persoonsgebonden Budget [Informal Care and Personal Budgets]. iMTA [Instituut voor Medische Technologie Assessment] Report 02.59. Erasmus MC, Rotterdam.

Wiener, J. M. 2003. Personal budgets in The Netherlands. In Wiener, J. M. and Tilly, J. Consumer-Directed Home-care in The Netherlands, England and Germany. American Association of Retired Persons Policy Institute, Washington DC.

Zarb, G. and Nadash, P. I994. Cashing in on Independence: Comparing the Costs and Benefits of Cash and Services. London, Policy Studies Institute.

Address for correspondence:

Accepted I4 December 2005

Virpi Timonen, School of Social Work and Social Policy, Trinity College, University of Dublin, Dublin 2, Ireland.

e-mail: timonenv@tcd.ie 